\title{
Mission from the margins: A reflection on faith by "women" displaced or trafficked into forced labour in the City of Tshwane ${ }^{1}$
}

\section{Leomile Mangoedi ${ }^{2}$ and Moraka $\mathrm{H}_{\text {Mogashoa }}{ }^{3}$}

\author{
Abstract \\ women at TLF reflected on the faith of a servant girl in the story of 2 Kings 5:1-4. \\ Bible Studies

\section{Introduction} \\ The remains of war, \\ belittled, orphaned, enslaved \\ but \\ humble, caring, faithful, self-confident \\ but \\ without a name, \\ yet \\ believing \\ and knowing \\ the name of God \\ and his servant Elisha.
}

This article is an engagement with a group of homeless women in the street of Tshwane. The Meal of Peace project, together with the Tshwane Leadership Foundation, seeks to engage with people on the margins of the city. It explores the economic challenges that expose women to trafficking. The article looks at how the

Keywords: Margins, Women, Trafficking, Forced Labour, Urban Mission, Contextual

1 This article was published as a chapter in the peer-reviewed book Pavement Encounters for Justice: Doing Transformative Missiology with homeless people in the City of Tshwane (Mashau \& Kritzinger 2014), that was a result of the Meal of Peace Project of the Dept. of Christian Spirituality, Church History and Missiology at Unisa. The editors and the authors (as copyright owners), have given permission that this version may be published in Missionalia, as an accredited South African journal.

2 Prop LM Mangoedi is a Research Assistant at the Department of Christian Spirituality, Church History and Missiology, at the University of South Africa (Unisa). Prop Mangoedi can be contacted at mangoel@unisa.ac.za

3 Prof HM Mogashoa is the Quality Assurance Practitioner at the College of Human Sciences, of the University of South Africa (Unisa) and can be contacted at mogashmh@unisa.ac.za 
We live in a society where the fundamental human rights of women (and girls) are still violated. In this article, our focus is on one such specific scourge, namely women displaced or trafficked into forced labour. The dialogue on this subject, in this article, will be between "ordinary" and "trained" readers of the Bible. We explore the voices of marginalised people (primarily women) in Tshwane from different parts of the African continent, as they discuss this subject during a Contextual Bible Study on 2 Kings 5:1-4.

In this article, we shall apply contextual hermeneutical lenses in reading the text, focusing on the exploitation of women ${ }^{4}$ who have been displaced or trafficked into forced labour. Our central focus will be on issues that emerged in the reading (the "what") as well as the "how" of their reading, when a group of women residing in the City of Tshwane tried to make sense of this passage. We also need to acknowledge that some homeless men were included in this Bible Study group. The women in the group came from different parts of the continent, many of them from Mozambique and Zimbabwe. There were also women from South Africa, who can be referred to as internally displaced migrants. These are women from other provinces of the country, who have come to Gauteng in search of economic opportunities.

Women who are trafficked or displaced are forced into vulnerable situations due to economic reasons. For foreign women, exacerbating their situation is their lack of work permits. We also note that some of these women were given false promises of work in Gauteng, only to discover that they would be displaced or trafficked into forced labour. Being displaced or trafficked not only strips you of your humanity and dignity, but also places you on the margins of society. If we take note of the secondary role of women, particularly black African women, their marginalisation is double-edged. They are marginalised because of their race and gender, and to be marginal is to be on the edge - neither central nor significant ${ }^{5}$. Being marginal puts one in potential danger, treated as a nobody, excluded by society and beginning to be socially disorientated.

Experiences of women and their marginalisation form the basis of this article. Therefore, the question that this article will address is "Can a young woman be an agent of change?" To unpack this, the article is laid out as follows: firstly, we explore why this topic was chosen; secondly, will give a description of the Bible Study method; thirdly, a definition of the concepts; fourthly, a discussion of themes that emerged from the Bible Study; and, lastly, a conclusion that synthesises the core argument and invites possible future research. All efforts have been made to ensure that the discourse stays as true as possible to the essence of the contribution by the participants in the Bible Study.

4 This scourge also affects young girls, but the focus of the article is not primarily on them.

5 International Bulletin of Missionary Research. Issue 27:4, October 2003. See http://www.internationalbulletin.org/files/html/2003-04-home.html Accessed on 2014/06/04. 


\section{Why this topic?}

The ugly reality of human trafficking in the City of Tshwane was brought to the attention of the public in July 2011 when a human trafficker, Adina dos Santos, was sentenced to life imprisonment by the Pretoria Regional Court (City Press $2011)^{6}$. Dos Santos, a 28 year old woman, was arrested in 2008 and charged with luring three teenagers, aged between 14 and 17 years, to South Africa, pretending to offer them work in her hair salon in Pretoria. She had met the girls on a beach in Maputo, kept them with her against their will, forced them into prostitution and pocketed the money they made (City Press 2011).

To initiate missiological reflection on the reality of the trafficking of women and girls, the story in 2 Kings 5 was chosen. It is about a young Hebrew $\operatorname{girl}^{7}$ who had been kidnapped by a Syrian para-military group during a raid and made a slave to the wife of Naaman, a high ranking Syrian officer. In this article, we explore the nature of modern slavery through two lenses: firstly, displaced women; and secondly, women trafficked into forced labour. The question which this article explores is whether this displaced and trafficked girl can be a mission agent? Most of the participants in the Bible Study identified from the text that the "agency" issue refers to "someone from the margins." We explore this idea later on in the article.

In giving words, imagery and meaning to this (trafficked and displaced) servant girl, Group 4 narrated her agency (poetically!) as follows:

I am the servant girl, sent with the good news like an angel, and came with good tidings of healing. About my situation I have no feeling. They thought that I was just a slave, not knowing that I have come to save the one whose wife I was meant to serve, asking for no gains or any special favour.

I never considered my own plight

for I knew that what I was doing was right, for the commander had a disease to fight which had no healing in sight.

In connecting to the above discussion, let us briefly speak about the women who were our main readers of this text. These women live at the Potter's House, most of them destitute and unemployed. The Potter's House is a

6 Check www.citypress.co.za/news/sa-sends-clear-message-to-traffickers-20110720/ (accessed on 2014/11/06).

7 The Hebrew expression used to describe her in 2 Kings 5:2 (na'erah qetanna) refers to a small girl. 
place of refuge for displaced women, located in the inner City of Tshwane. ${ }^{8}$ Mission from the margins, therefore, calls on "the agent" to carry out "the agency." The space to carry out the agency is a contested space. Our times (and space) are materialistic and our economy is capitalistic. The self-accumulation is done at the peril of those on the margins. Material resources, therefore, are used to describe one's role and status in the contested space. However, the scriptural text that is our focus invites us to grapple with an agent with few or no resources who becomes influential in carrying out the agency.

\section{A description of the Bible Study: Methodology}

The method used in conducting the Bible Study is called Contextual Bible Study (CBS). ${ }^{9}$ CBS promotes a participatory action research methodology. The CBS tool was developed by Gerald West $^{10}$ and promotes interaction between a facilitator and participants. Furthermore, both the participants and facilitator are expected to come up with an action plan. The facilitator plays a critical role in the process. West draws on five aspects that the facilitator should espouse. These are:

[T] he facilitator should use a method that encourages the whole group to participate; the facilitator should manage conflict and make the group a safe place for member contributions; the facilitator should train others to become facilitators; the facilitator should clarify what is not clear and should summarise the discussion; and the facilitator should enable the group to become aware of and involved in the needs of the community (West 1995:228). ${ }^{11}$

For our Bible Study we read 2 Kings 5:1-4, using the New King James Version. The Bible Study focused around these five questions:

(a) What was the text all about?

(b) Who are the main characters?

(c) As a small group, prepare to re-tell this story by drawing a picture or doing a drama.

(d) What is the untold story of a young slave girl who is the key agent in this story?

8 For more information on the Potter's House, see http://www.tlf.org.za (accessed on 2014/05/21).

9 The CBS was also used in the workshops under Tshwane Leader Foundation (TLF). TLF is an organisation working with the churches and communities for urban transformation. For more on TLF, see http://www.tlf.org.za (accessed on 2014/05/13).

${ }^{10}$ Gerald West is a Theology Professor from the University of KwaZulu-Natal, South Africa.

${ }^{11}$ West, G. 1995. Biblical Hermeneutics of Liberation: Modes of reading the Bible in the South African context. Cluster Publications: Pietermaritzburg. 228. 
(e) What untold stories in your context does the telling of this story bring to your memory? Tell your stories to each other in your small group. ${ }^{12}$

Our Bible Study was comprised of young women (between 18 and 25 years of age) and middle-aged women (between 35 and 50 years of age). These women, as indicated before, are housed at the Potter's House. We also had in the Bible Study group a group of homeless men who were middle-aged (between 35 and 50 years of age).

The actual interaction during the Bible Study was as follows: firstly, following the answering of Question 1 by individuals in the plenary (all participants together), the group was divided into four sub-groups. Each of the sub-groups had five or six people in it. Secondly, we then allowed interaction to be at the sub-group level. From the interactions that took place, we found the responses from these ordinary readers to be both "strange" and "exciting." For us, the "trained" readers, we thought human trafficking or slavery was explicit and was the main issue in the text. To our surprise, human trafficking was not the main issue for the ordinary readers. Rather, they focused on and held high the faith of the slave girl and the power of God manifesting through Naaman. In our encounterology - whereby we listen to the voices of the ordinary about this text - we shall come across their direct articulation later in the article.

Kritzinger (2008:770) defines "encounterology" as a relationship between missiology and other disciplines, reflecting on all the factors shaping the intentional encounters between followers of different religious ways. This approach encourages dialogue between people of different cultures and religions. It also seeks to integrate theology and mission. It creates a space where trained readers will have an encounter with the ordinary readers and the two will listen to each other. The Bible Study organised by the Meal of Peace ${ }^{13}$ provided that space.

\section{Definition of Concepts}

\section{Human trafficking}

Trafficking has many classifications. It can be classified as a form of sexual exploitation, forced labour or any form of slavery. According to The Prevention and Combating of Trafficking in Persons Act, 2013 (Act no. 7 of 2013):

12 Doing Contextual Bible Study: A Resource Manual. Ujamaa Centre for Biblical and Theological Community Development and Research. 2011.

13 The Meal of Peace project is a diaconal ministry and research project for the homeless in Pretoria. The aim is to design interventions to eradicate extreme poverty and hunger; combat HIV, AIDS, malaria and other diseases; and to ensure environmental sustainability. For more information, see http://www.tlf.org.za (accessed on 2014/05/13). 
Trafficking in persons shall mean the recruitment, transportation, transfer, harbouring or receipt of persons, by means of the threat or use of force or other forms of coercion, of abduction, of fraud, of deception, of the abuse of power or of a position of vulnerability or of the giving or receiving of payments or benefits to achieve the consent of a person having control over another person, for the purpose of exploitation.

O'Connor (2013:3) picks up three phrases which stand out in the definition, namely: (i) recruitment (ii) transportation and (iii) exploitation. These terms capture the nature of traffickers. They deny their victims any sense of freedom, dignity and human rights. The victims (of the traffickers) are mostly women and children. They are bought and sold like property belonging to an individual (O'Connor 2013:3).

The young girl in the book of 2 Kings was taken captive and made to work for Naaman's wife - from which we can infer that the latter was labour-exploited. The only detail we know of her is that she was a young girl and a foreigner in Syria. In our South African context, traffickers usually capitalise on endemic poverty and unemployment (O'Connor 2013:6). We also witness situations of foreign women being trafficked. The need to overcome poverty causes the victims of human trafficking to be desperate, causing the traffickers, in turn, to identify their prey quickly. According to O'Connor (2013:6), South Africa is referred to as the "economic giant of Africa, and therefore seen as a source, destination and transit country for human trafficking." O'Connor, in addition, identified the problem of uncontrolled border posts. South Africa shares borders (through SADC agreements) with Lesotho, Mozambique, Zimbabwe, Namibia, Botswana and Swaziland, which makes it easier to export and import victims in and out of South Africa. Furthermore, there are harbour ports through which victims of human trafficking can enter the country by ship.

\section{Forced Labour and Slavery}

Firstly, let us start with the definition of forced labour. According to the International Labour Organisation Convention No. 29 of 1960, forced labour means "all work or service which is exacted from any person under the menace of any penalty and for which the said person has not offered him/her voluntarily." In this article, "voluntary" means a work that is performed by a person who is fully aware of what the work entails and in full agreement to abide by the contract signed. By contrast, "involuntary" work means working because someone has forced, confined and manipulated another to work. In most cases, it would be work under unfavourable conditions: "Forced labour can never be used for economic development or as a means of political education, discrimination, labour discipline, or punishment for having participated in strikes" 
(ILO Convention No. 105 1957:3). ${ }^{14}$ Most of these girls and women are vulnerable to trafficking due to destitution, unemployment and family crises. Trafficking as a form of forced labour is a crime that affects girls and women on a daily basis. It has become popular in those societies suffering from poverty, unemployment and homelessness. The trafficked (the victims) are sent or found in economically active places - and the City of Tshwane is no exception.

Secondly, let us come to the definition of slavery. Slavery, according to the Sexual Offences Amendment Act No. 32 of 2007, means "reducing a person by any means to a state of submitting to the control of another person, as if that other person were the owner of that person." According to O'Connor (2013:xii), there are people who do not believe that slavery still exists, but through her book she demonstrates how destructive slavery is now, even more than in former times. When compared to the Transatlantic Slave Trade, in our current times (to be emphatic) thousands of women and girls are continuously being shipped into brothels each year (O'Connor 2013: xii).

\section{Themes emerging from the Bible Study: mission praxis encountered}

\section{Spiritualising slavery: when faith and prayer are a necessary resource}

The Bible is a highly-respected source amongst the black communities. Many ordinary readers do not want to be critical of the Bible. Even when the message of a Bible story clearly speaks the message of a just God who is concerned about the downtrodden, and the downtrodden are equipped with resource tools to be critical of the story, many would prefer to "spiritualise" it (with an escapist, heaven-bound preoccupation) and apply some avoidance ("leaving it all to Jesus") from meaningfully engaging with their situations of hardship and pain.

The spiritualising of hardship and pain tends to serve as a coping mechanism to make sense of life. This is not about denial per se, but a means of gaining strength to face life, cope with their existence of hardship and to use a resource (faith in this case) that is so personal that it cannot be taken away from one's being. Faith in God is used to spiritualise matters when one has no material resources to use in order to address the challenges of life.

Group 3, in acknowledging the ruins of war and that the slave girl was captured and removed from her family, defined the experiences of the slave girl as follows: "Belittled, orphaned, enslaved, but humble, caring, faithful, self-confident, but without a name, yet believing and knowing the name of

14 The Abolition of Forced Labour Convention, 1957 (No. 105). ILO Convention No. 105. See http:/www.ilo.org/wcmsp5/groups/public/---ed_norm/---normes/documents/publication/wcms_100663.pdf (accessed on 2014/07/28). 
God and His servant Elisha" (quoted at the beginning of the paper). Faith can be an enigma - a paradox and a perplexity. Group 3, in defining the ruins of war and how the slave girl was affected by war, still defined the victim of war as caring and faithful!

Many of the foreign women who participated in the Bible Study have had direct experience of being belittled and orphaned by war. They experienced this in the form of civil war in their respective countries. The Democratic Republic of Congo (DRC) went through a number of civil wars, and among the women in the Bible Study were also women from the DRC. Many of the women could identify with this girl who was orphaned by war.

In the above quotation from the members of Group 3, the concepts that the members of the group used are loaded with meaning and relate to their experiences. For example, the concept of being "enslaved" for many women who are also working as domesticated urban poor women (see 5.4. Domesticating enslaved urban poor women) find that their domestic employment is daily enslavement: the sleeping quarters, the treatment meted out to them by their employers and the children of the employers, and the constant fear of being discovered by police officials due to their illegal status in the country. Therefore, faith in God and the spiritualising of hardship serves as a tool, believing that God will rescue them from their hardship. At night time when their employers are asleep, this serves as a time for them to reflect deeply on their faith in God in their context of domestic work and to re-connect deeply with God in prayer.

Prayer is a crucial tool in communicating one's pain and hardship to God; a release, emotionally and psychologically from a life of enslavement without knowing how to escape physically. The deep tears flooded physically taxing - but weeping prayer serves as a release and an assurance to the victim of the abusive master that she has finally told it all to Jesus who did listen and will answer.

The following story, by one of the women in the Bible Study who went through abuse, speaks to this point:

I was once one of the women at the Potter's House and I had a newly-born child who had two disabilities: he was blind and deaf. I believe[d] in God the Healer: I prayed and trusted God for his healing. My disabled baby was miraculously healed. Now 14 years old, he is healthy, strong and a child of God. Thanks God.

\section{Migration and xenophobia}

The growing number of migrants in South Africa is a contemporary challenge that the government is trying to address. Internal migrants are those South Africans relocating from one part of the country to the other, primarily for economic reasons. The number of South Africans moving from the rural parts of the country to the cities has often resulted in the 
cities experiencing pressure in trying to accommodate these internal migrants. These internal migrants are not only competing for resources against other South Africans; they need to compete for these economic resources against the foreigners from outside South Africa as well.

In conducting the Bible Study, one of the questions was: What untold stories in your context does the telling of this story bring to your memory? The question helped to unearth the topic of migration and xenophobia. The women in the Bible Study could identify with the experiences that the slave girl went through in Syria - a foreign land. Different from the slave girl, who entered Syria as a result of being captured during a raid on her homeland of Israel, the foreign women in the Bible Study entered South Africa willingly, in search of economic opportunities. The lack of economic opportunities these women experienced in their home countries caused them to look to and come to South Africa, in an attempt to improve their lives. Poverty tends to push people into economic migration. Due to the dire need to overcome poverty - and the efforts that people go to in order to escape poverty, including entering South Africa illegally - these women were aware that exploitation might possibly occur. Furthermore, due to lack of specialised skills, domestically-related jobs are the jobs that most foreign women also tend to take. The foreign women could relate to the domestic experience of this slave girl - a foreigner, who worked as a domestic worker in the household of Naaman (see the section on "Domesticating enslaved poor urban women").

Coming back to the issue of being a foreigner, together with the fear and suspicion that South Africans have concerning foreigners (xenophobia), the issue of one's name, coupled with one's identity, comes into play. Noting that most of these foreign women entered South Africa illegally, they are officially, according to the records of the country, nameless. It is one thing to be nameless ${ }^{15}$ while the officials of the foreign country know that you are there - which was the case with this young girl - and quite something else to be nameless in a country where you are present illegally and the officials can discover you at any moment - which is the case with most of the foreign women who were part of the Bible Study. When you are a foreigner and it is officially known that you are in the country, there is a modicum of protection. But when you are a foreigner and it is not officially known that you are in the country, you are prone to different types of abuse and often with no protection guaranteed. Most of the foreign women are prone to abuse by the South Africans (both males and females), abuse by foreign men (whether they entered South Africa legally or illegally), and abuse by foreign women (often those who entered South Africa legally or those whose stay in South Africa has been made official).

15 The narrative in 2 Kings 5 doesn't contain the young girl's name. 
In terms of the slave girl, inferences can be made regarding her experience of abuse: abuse by the Syrians, abuse by the household of Naaman and abuse by a fellow woman who was her mistress (Naaman's wife) (see Verse 3). To elaborate: the Syrians perceived her as "a young girl from the land of Israel" (see Verse 2); and Naaman also perceived her as "the girl who is from the land of Israel" (see Verse 4). These ways of qualifying her by her land are also how foreign women in South Africa have been qualified too, during their time in South Africa: "a woman from Zimbabwe" or "a woman from the Congo", for example. This categorisation by land creates a sustained perception of how people from outside South Africa are perceived.

Because perception limits the movement and the quick economic progress these foreign women hope to achieve in Pretoria (or Gauteng), they tend to resort to desperate means to survive. Firstly, noting that the issue of identity is critical in order to survive in a foreign land, the need to acquire a South African ID document is critical. But noting that most entered South Africa illegally, an illegal means of acquiring the ID tends to be the practice.

Secondly, sexual favours are explored in order to gain proper residency and ID documentation. Even if it means being married without love and commitment to marriage, the desperate state of many foreign women pushes them to do this. Such desperation leads to further exploitation and abuse.

Thirdly, because these foreign women would like to belong, they try as much as possible to re-appropriate their names to suit the Pretoria context they find themselves in. For example, women from the Congo (a name commonly used among South Africans to refer to the Democratic Republic of the Congo DRC), they tend to use the English equivalent of their French names.

Whatever the desperate means these foreign women use to survive in Pretoria, underlying everything is that "the foreigners felt insecured [sic]" - a statement articulated by Group 5. The group further explained xenophobia as follows, with reference to actual experiences that unfolded in South Africa:

This was a time when foreigners were attacked and killed. Some were burnt alive. I saw people (mothers) running with their children to save their lives. The children were crying, not even knowing what was going on but only asking for food, which food could not be provided.

The slavery that the slave girl experienced does speak to the slavery that the foreign women in the Bible Study felt. Moreover, those who entered South Africa illegally, without having it officially documented that they were in South Africa, are still without formal identification and are prone to having their slavery experience compounded even further. 


\section{On being nameless}

In reading the text from the Bible, it is clear that the "slave girl" is not referred to by name, nor is her family mentioned. The New King James Version refers to her as: "a young captive girl from the land of Israel" (verse 2). In the text, her existence as a person in the social interaction with the family of Naaman is one of no authentic identity. Noting that the Syrians were strong in warfare, could carry out raids at will, and had just raided Israel, the reference to this young girl as coming "from the land of Israel", further affirms the lesser value they attached to her. She is just one of the "spoils" gained from the raid.

In contrast to the other four persons' characters found from Verse 1 to 4, three are clearly identifiable, while one is not. They are: Naaman (clear identification), Naaman's wife (identification by association), the slave girl (no identification) and the master of Naaman (identification by association). The slave girl had no identification. Anyone can be referred to as a slave girl. It is a "disposable reference" and can be used at will after the first one (slave girl) is disposed of. There are therefore no clues of value in qualifying the identity of this slave girl. Group 3 in the discussion succinctly captured the definition of this girl as a slave girl, "but without a name."

The question of what her name was is crucial in unpacking the unfolding discourse. The discourse in the Scripture confirms that there is no value attached to this slave girl. The discourse among the characters in the story also confirms this. The discourse by the author of the text further confirms this. Lastly, the discourse that unfolded during the Bible Study session, also confirmed this - a slave girl, "but without a name."

Because of the lack of the real name of this slave girl, the reference to her as "a captive young girl from the land of Israel" (Verse 2) is what now defines her. When a person has no real name, many inferences and definitions are applied to him or her. Naaman, in communicating with his master, refers to the girl as "the girl who is from the land of Israel." Clearly, she is seen as being of no value, an outsider (foreigner) "from the land of Israel" - a reference always made in describing her. This means, in addition to being a captive, a young girl, she is further qualified as a foreigner. Being nameless is very painful, as you are seen as the "Other" ${ }^{16}$. You are described as something of no value by those with powers to describe.

16 The signifying economy of otherness, according to the Comaroffs (1991:105), took in gender as well as race. Biology was invoked to explain the division of labour [domestic work for the slave girl in our case] already established in the economy. The Other is made peripheral, but was to fit into the material and imaginative order of the one with the power to define the "Othering" of the "Other", yet deprived "the Other" of access to the highest values and benefits those at the centre enjoyed. The continued process of "Othering" is about the simultaneous process of inclusion and disqualification between the centre and the periphery. For more on the discourse of "the Other", "Otherness" and "Othering", see Comaroff, J. \& J. 1991. Of Revelation and Revolution. Chicago: University of Chicago. 
Being described as the "Other" by those with the resources to do so, speaks to the issue of power relations. Let us also recall that this girl is described in belittling terms in the land of those with the power to do so. She cannot protest against her description, since she is after all a property gained from the rewards (spoils) of the raids. For quicker reference in this article, we shall refer to this young girl as the "slave girl."

By being nameless, the slave girl has lost her identity. Without one's name, there is no identity. Attached to a name is the history of the family and the land that one comes from. The tragedy that the slave girl experienced is more than a double tragedy. She is dispossessed and displaced from her identity, her family, her history and her land, while many other associations of life with her people are now lost in the foreign land. We shall refer to her tragedy as a "multiplied tragedy." The tragedy has such manifold aspects that it just keeps unfolding in the foreign land where she is now a captive. Group 1 in the Bible Study session described this young girl as one who "suffered great loss." Observing that she is now disconnected from her people, her stability has been turned into instability and she is now without the protection of her family and associates which came about as a result of being part of a collective group in her native land. Her affirmation of space and protection is lost.

The lessons on "being nameless" are very much applicable to the participants from the Bible Study. All the above lessons resonated with the participants. The participants, with many of them coming from outside South Africa, could identify with the "foreigner" experience (see 5.2. for more discussion) that the "slave girl" experienced in the land of Syria. The concept of foreigner also speaks, to some degree, to "internal migrants" within South Africa, who relocate from different parts to come to Gauteng to seek employment opportunities. The Bible Study group meeting was conducted in Pretoria which is located in Gauteng, not forgetting that Pretoria is also the capital city of South Africa. Power relations are at play in a place where one is seen as the "Other", a "nameless Other" in "our space," whether you are a foreigner from outside South Africa or an internal migrant (who comes from outside Gauteng).

\section{Domesticating enslaved urban poor women}

Poverty strips one of dignity. Moreover, being poor and being away from one's family, the people that one grew up with, or away from one's own country, exacerbates the experience of being poor. Many people move away from their places of origin and away from their families in search of economic opportunities. So, too, the women who were part of the Bible Study came from different backgrounds of poverty, with many of them also being foreigners in South Africa. They are away from their home backgrounds, their countries of origin and are in the City of Tshwane (also referred to as Pretoria) in search of economic opportunities. The same applies to women who are internal migrants. 
Since most of these poor women who enter the city (and South Africa specifically) in search of economic opportunities, do so often without the formal legal papers (especially in the case of the foreign women) that are required to be legally in South Africa, such women often acquire work as domestic workers. They work long hours each day, and often seven days a week. Their salaries are lower than the accepted salary that the government stipulates for domestic workers. At times, the small amount of identity-related papers, with which they might have entered South Africa is taken for "safe keeping" by their employers. Often, this is not about "safe keeping" at all, but rather holding these workers to ransom and keeping them indebted to their employers. This makes it difficult for these workers to leave if they are not happy with their conditions of employment.

At times, many of these foreign women have to work for months without pay, as a way of "paying out" the costs that their domestic employers "incurred" in ensuring that they have a "safe stay" in South Africa, with shelter, food and a job. This kind of treatment meted out to the foreign women working as domestic workers in the city communicates a description of these women as domesticated, enslaved, poor urban women. A number of the foreign women who participated in the Bible Study have had such experiences. With reference to the text, Group 2 and Group 3 respectively referred to the slave girl from Israel as a domestic worker in the house of Naaman.

On the topic of domestication, let us briefly reflect on its discourse as it unfolds in a materialistic setting. Domestication is more than just working as a domestic worker; residing in the household of the employers; or just being offered food and related amenities coming with shelter. Domestication is rather a systemic subjugation and the total control of one by the other. It is about the exercising of power by the person who is in charge of the space (domestic household) and has the material resources to exercise this power. Domestication is about the dehumanisation of the other person, whose sole purpose in the domesticated space is to serve the interests and wishes of the master - who is the owner of the domestic space. The impact of the effect of domestication can also be psychological and spiritual. At times, the domesticated women are not allowed to have friends and other people knowing where they are working, to the extent that they are sometimes not allowed to speak or be seen speaking to other people in the neighbourhood. The domesticated person is more like an "owned property" to the master and his or her household.

As to the spiritual effect of domestication, in order for one to have a better perspective into the effect of domestication on women working as enslaved, poor urban women, one needs to attend one of the prayer meetings of these women held by themselves. Prayer, singing and their interpretation of the Word of God do serve to communicate and process 
their domestic work experiences, showing how faith helps to serve as a release of "burdens on the heart" (see the section on Spiritualising slavery).

The following poem by Group 2 captures some of the issues involved when domestication and the spiritualising of hardship go together. The groups were asked during the Bible Study to each draft a poem reflecting the experiences of the slave girl. Here is what Group 2 presented:

Our country was raided by the Syrian soldiers.

Both my parents were killed in action.

I was taken as a slave to Syria.

The commander-in-chief made me his domestic worker.

The wife was so good to me.

I told her about the prophet in Samaria, who had magic hands

Which lead one [to be] healed in seven days, and he was cured for life.

\section{Master-slave relations}

The scripture without delay introduces the young girl as a captive whose duty was to wait on Naaman's wife (see Verse 2). During the Old Testament times, there were two alternatives: being a slave by serving in a household or being a slave by imprisonment. The young girl from the land of Israel experienced both. She was a captive due to the raid and she also had to serve Naaman's wife in Naaman's household.

The scripture, which is our text of focus, introduced Naaman - the master, "as a great and honourable man in the eyes of his master" (Verse 1). The reason for him to be such is: "because of him, the Lord had given victory to Syria" (Verse 1). The scripture further emphasises that he "was also a mighty man of valour [courage and bravery]." Adding to that, Group 2 during the Bible Study session defined Naaman as "highly respected."

Noting that this slave girl had the duty of serving the wife of Naaman, one of the questions that the Bible Study asked the groups to address was:

- Who are the main characters in the story and what do we know about them?

Surprisingly, all groups identified Naaman, the slave girl and the prophet Elisha. Not a single group identified the wife of Naaman, whom this slave girl had to serve. In the four verses (Verses 1 to 4 ) that were the focus of the Bible Study, two verses speak about Naaman's wife, but nevertheless none of the groups identified her as a character in the story. Furthermore, the duty of the slave girl was to serve Naaman's wife, yet the groups did not identify Naaman's wife as one of the characters in the story! The groups therefore "read out" Naaman's wife from the text. 
The "reading out" of Naaman's wife adds another aspect to our discussion of the master-slave relation. The "mistress," Naaman's wife, was not "noticed" by any group as one of the characters in the story. The slave girl, therefore, is defined and characterised in terms of the "male" owner of the house - who is Naaman. The mistress, who is the wife of the master (Naaman), was not regarded as a significant character by any of the participants. The determining person in the context of the house, according to the groups, is therefore the master, Naaman.

There is no doubt that the mistress could have determined the kind of slave girl she might have wanted to serve in her household, since such a slave girl would have to work closely with her, as the text stated: "She waited on Naaman's wife" (Verse 2). Irrespective of the fact that the mistress had great influence on the type of slave that she wanted, the groups defined the slave girl in relation to the master, Naaman. The "elimination" of Naaman's wife from the household relationships in Naaman's house does suggest some sympathy that the women from the Bible Study felt towards Naaman's wife. It seems to suggest that she behaved as a mistress due to the demands of the master. Furthermore, the women from the Bible Study seemed to propose that, irrespective of the fact that the two women - the slave girl and Naaman's wife - were from two different backgrounds nationally and economically, there seems to have been solidarity among them as women. A woman does know the subjugation that a fellow woman - who might also be "the Other" - feels. In addition, the "reading out" of Naaman's wife does reflect on the conceptions that black women (bearing in mind that the Bible Study consisted mainly of black women) have about property. The house and the household are perceived in patriarchal terms of the primary owner as a man - the "head of the house."

Master-slave relations are about power and powerlessness. The master has power, while the servant has none. The slave is powerless in that she is a captive and she is also a servant (domestic worker) in a foreign land. She is not just a domestic worker in any other house, but in the house of the man who oversees the wars, and from one of these (wars) she is a victim.

Next to the powerlessness of women within the household controlled by a man, is the possibility of sexual favours expected from the servant woman in the household - which in our case is the slave girl whom the text further refers to as young (Verse 2). One of the questions asked in the Bible Study expected the groups to allow members to share their experiences. From Group 3, one woman narrated her story of abuse - in particular, sexual abuse. From the abuse a child was born, who unfortunately had two disabilities: blindness and deafness. Faith in God became a resource for this woman, who trusted and relied on God for the healing of her child (for this narrated story, see the section above on "spiritualising slavery." 
In situations of power versus powerlessness, master versus servant relationships - being situations that women often go through - faith in God serves as a resource, among the many resources that women use to overcome abuse. Many foreign women who were part of the Bible Study could identify with the nature of the master-slave relationship that this slave went through in the house of Naaman, as personifying what they went through in the households of their masters, here in the City of Tshwane (Pretoria) where they worked.

\section{When the slave is the provider of critical help}

Life in the household of Naaman, who was a leper, was on the fringe. Leprosy was an incurable disease. Even though Naaman's family was doing well materially and in terms of its social standing in society, the leprosy of Naaman stood in the way of the "perfect" and "comfortable" family and the "successful career" that Naaman and his family could have had. Even though Naaman was an accomplished, acclaimed and highly-respected leader of the army, his leprosy condition obstructed the "perfecting" of his accomplishments.

Leprosy was a disease that often caused the people who had contracted it to be isolated from society. However, in the case of Naaman, his successes as a leader of the army of Syria and the fact that he was a man of "valour" (courage and bravery) meant that his leprosy condition did not solely define him. The text immediately describes Naaman's state, as follows: "He was also a mighty man of valour, but a leper" (Verse 1). Thus, his leprosy is secondary, and his accomplishments as a commander of the army are first. His good and strong leadership in the army had obviously earned him respect.

Without negating the above, let us further reflect on the leprosy of Naaman. For example, could it be that he was a man of valour, always ready for war and fearless, because the leprosy he had made him accept the fate of a disease that was incurable? His life seems, apparently, to be one of racing against time, bearing in mind the lethal nature of leprosy! The cost of remaining healthy and always fit as a commander of the army was high: he had to manage the illness of leprosy on the one hand, set against his work as a commander of the army and a husband on the other hand. Given these demands, any opportunity of overcoming the leprosy was welcomed. Much depended on his recovery.

However, help came from the least likely source. Group 4 in its discussion referred to the young girl (the slave girl) as the one who initiated change in the story. Not much was expected from the slave girl, except for her to be busy with the usual errands of a slave girl working in a household. However, unbeknown to the household of Naaman, she was much more than a captive and a slave girl. Her life and character were rich with faith and spirituality. 
Known merely as a captive and a slave girl in the land of Syria, her nature, character and spirituality were not known. Her faith from her background was to serve as a catalyst for Naaman's healing. Her displaced background and poverty was possibly to serve as the source of Naaman's answer to his healing. From a person of no social standing (slave girl) was to come the answer for a person of great standing and stature in society (Naaman).

For her to share her knowledge of where healing can come from for Naaman, it shows that she had inbuilt resilience to transcend her humiliating slave status. She provided help to one who facilitated her capture and who turned her into a slave for his household. She did not, surprisingly, use her knowledge to bargain her way out slavery. It takes someone with a deep-rooted faith in God, to have done what the slave girl did. What is problematic, however, is that she did not bargain her way out of being a slave to Naaman's household. This reminds us of an earlier discussion about the "problem of spiritualising poverty." It would in fact be quite acceptable for any slave to rejoice over the suffering and ill-health of a master who plundered her home and turned her into a slave at a foreign land. However, the slave girl offered help and a critical answer to Naaman whereby his healing could be found.

Spirituality and faith in God humbles us all to accept that we are all equal before God and that we complement each other. Group 4 captured such an idea, as follows: "Before God we are all equal, as we complement each other." For the slave girl to assist Naaman, even after she was a slave in his household could only be possible as a result of forgiveness. The women from Group 5 in the Bible Study compared this forgiveness to that of the late Mr Nelson Mandela. These are the exact words as written down by the group:

"It is the story [the] same as Mandela who was in prison being enslaved by the Boers [of] Apartheid for 27 years. He manage[d] to forgive them as did this young little maid, when she told Naaman about prophet who can heal him. Although she was being enslaved also as his wife's slave, she also forgive [sic] about being a slave."

\section{Displaced and trafficked girls/women as mission agents}

Mission, according to the Study Guide of Patterns of Mission Praxis, is defined as "being sent." Bosch, using the definition that came after the sixteenth century, associates mission with the doctrine of the Trinity, which is the sending of the Father, Son and Holy Spirit (2005:1). It was regarded as referring to an individual who was sent to spread the gospel among non-Catholic Church members (2005:1). He further distinguishes between mission and missions. Mission refers to the missio dei, while missions refers to the activities of churches, the particular forms, related to specific times, places or needs, of their participation in the missio dei (2005:10). 
In the context of this paper, mission is referred to. The concept of missio dei - God's mission - expresses "God's self-revelation as the One who loves the world, God's involvement in and with the world, and in which the church is privileged to participate" (2005:10). The servant girl in the story demonstrated the reign of God and that "God is a God-for-people" in the household of Naaman. She was perceived as a slave, her dignity and humanity were undermined, yet she still carried out the mission of God through the implementation of justice and the maintenance of peace in the household of Naaman.

According to the Matthew Henry Concise Commentary, the Syrians oppressed the Israelites. Even though that was the case, the slave girl recommended the Israelite prophet for the ailing Naaman. Her role is distinguished in this story by the role she plays in desiring the health and welfare of her master (Matthew Henry Concise Commentary: 2014) ${ }^{17}$ Her servanthood turned into a blessing to the family of Naaman. The servant girl took a stand from the periphery as a mission agent. "Agency, whether in the social, political, ecological or economic spheres, is generally understood to entail some aspect of moral consciousness, an awareness that something is wrong somewhere and it has to be transformed" (LenkaBula and Makofane 2008:11).

\section{Conclusion}

Mission has played out its role in this article. Although the servant girl came from a marginalised and oppressed position, she was able to provide help. The women who participated in the Bible Study were able to relate to the story, especially in the way they reflected on faith. The discussion uncovered how vulnerable ordinary readers can be when engaging the Scripture. Masenya (2005:741-751) challenges the whole notion. According to her, an African person was trained to read the Bible as if he or she was a white person and steeped in elitist hermeneutics. This approach alienated the poor who tried to read the Bible. Ordinary readers look at the Bible from a "spiritualised" perspective. According to Masenya (2005:742), the Bible should not be distanced from the harsh realities on the ground. Pui-Lan (2005:103) affirms Masenya when she says that " $[\mathrm{t}]$ he meaning of the Bible is no longer seen as located in the authorial voice of God, or in the intention of the author or the redactor, but increasingly in the interpretive community."

${ }^{17}$ See http://www.christnotes.org/commentary.php?com=mhc\&b=5 Accessed 2014/11/11 


\section{Bibliography}

Bosch, David J. Transforming mission: Paradigm shifts in theology of mission. Orbis books, 1991.

Comaroff, Jean \& John. (1991). Of Revelation and Revolution. Chicago: University of Chicago.

International Bulletin of Missionary Research. Issue 27:4, October 2003. See http://www.internationalbulletin.org/files/html/2003-04-home.html

International Labour Organisation Convention No. 29 of 1960.

Kritzinger, J. N. J. (2008). Faith to faith - missiology as encounterology. Verbum et Ecclesia, 29(3), 764-790.

LenkaBula, Puleng, and Karabo Mpeane Makofane. Women's Moral Agency, Governance and the Quest for Justice in Africa. (2008).

Lutya, T. M. (2012). Human trafficking of young women and girls for sexual exploitation in South Africa.

Masenya, M. (2005). An African methodology for South African Biblical sciences: revisiting the Bosadi (womanhood) approach. Old Testament Essays, 18(3), p-741.

O'Connor, M. (2009). The Church and Human Trafficking. Dorpspruit: Cluster Publications.

Prevention and Combating of Trafficking in Persons Act, 2013 (Act no. 7 of 2013). www.justice.gov.za/legislation/acts/2013-007.pdf

Schreiter Robert J. 2002. Constructing Local Theologies. Maryknoll: Orbis Books.

Sexual Offences Amendment Act No. 32 of 2007.

The Abolition of Forced Labour Convention, 1957 (No. 105). ILO Convention No. 105. Check http://www.ilo.org/wcmsp5/ groups/public/---ed_norm/---normes/documents/publication/wcms 100663.pdf

Tshwane Leadership Foundation, http://www.tlf.org.za

West, G. (1995). Biblical Hermeneutics of Liberation: Modes of reading the Bible in the South African context. Cluster Publications: Pietermaritzburg. 